\title{
1 The global rarity of intact coastal regions
}

2 Brooke A Williams ${ }^{1}$, James E M Watson ${ }^{1,2}$, Hawthorne L Beyer ${ }^{1}$, Carissa J Klein ${ }^{1}$, Jamie

3 Montgomery $^{3}$, Rebecca K Runting ${ }^{4}$, Leslie A Roberson ${ }^{1}$, Benjamin S Halpern ${ }^{3,5}$, Hedley S Grantham ${ }^{2}$,

4 Caitlin D. Kuempel ${ }^{6,7}$, Melanie Frazier ${ }^{3}$, Oscar Venter ${ }^{8}$, Amelia Wenger $^{1,9}$

51 School of Earth and Environmental Science, University of Queensland, Queensland, Australia

62 Wildlife Conservation Society, Global Conservation Program, New York, USA

73 National Centre for Ecological Analysis and Synthesis, University of California, Santa Barbara, California

84 School of Geography, The University of Melbourne, Parkville, Australia

95 Bren School of Environmental Science and Management, University of California, Santa Barbara, California, 10 USA

116 Australian Research Council Centre of Excellence for Coral Reef Studies, University of Queensland, St.

12 Lucia, Queensland 4072, Australia

137 Centre for Biodiversity and Conservation Science. School of Biological Sciences, University of Queensland,

14 St. Lucia, Queensland 4072, Australia

158 Natural Resources and Environmental Studies Institute, University of Northern British Columbia, Prince

16 George V2N 4Z9, BC, Canada

179 Wildlife Conservation Society, Global Marine Program, New York, USA

\section{Abstract}

Management of the land-sea interface is considered essential for global conservation and

sustainability objectives, as coastal regions maintain natural processes that support

biodiversity and the livelihood of billions of people. However, assessments of coastal regions

have focused on either strictly the terrestrial or marine realm, and as a consequence, we still

have a poor understanding of the overall state of Earth's coastal regions. Here, by integrating

the terrestrial human footprint and marine cumulative human impact maps, we provide a

coastal areas globally can be considered having low anthropogenic pressure, mostly found in

Canada, Russia, and Greenland. Conversely, $47.9 \%$ of coastal regions are heavily impacted

by humanity with most countries $(84.1 \%)$ having $>50 \%$ of their coastal regions degraded.

Nearly half (43.3\%) of protected areas across coastal regions are exposed to high human 


\section{$34 \quad$ Introduction}

35 Coastal regions encompass some of the most biodiverse and unique ecosystems on Earth,

36 including coral reefs, kelp forests, seagrass, tidal flats, mangroves, estuaries, salt marshes,

37 wetlands, and coastal wooded habitat (Ray 1991). The persistence of many species relies

38 upon processes that occur across the coastal region including breeding, foraging and

39 migration of both terrestrial and aquatic species (and species that inhabit both systems),

40 nutrient exchange, riverine inputs, and tidal flow (Hazlitt et al. 2010; Fang et al. 2018).

41 Coastal ecological processes underpin critical ecosystem services to humanity like fisheries

42 (Barbier et al. 2011), storm protection (Barbier 2015), and carbon storage and sequestration

43 (known as "blue carbon") to help mitigate climate change (Mcleod et al. 2011). As a

44 consequence, intact coastal regions (i.e., those that have relatively low human pressure) are

45 critical for maintaining natural processes that support biodiversity and ecosystem services

46 (Fang et al. 2018). These ecosystem services are relied upon by billions of people for their

47 livelihoods (Cinner 2014) and wellbeing (Vo et al. 2012).

48 Coastal degradation from anthropogenic activity has resulted in profound declines in

49 biodiversity and ecosystem services. For example, the destruction of coastal habitats is

50 leading to declines in adult coral reef fish populations, such as the economically valuable

51 bumphead parrotfish (Bolbometopon muricatum; Hamilton et al. 2017). Many species can

52 only persist in coastal ecosystems with high levels of ecological integrity. The marbled

53 murrelet (Brachyramphus marmoratus), a seabird from the North Pacific, is an example of a

54 species that relies upon old growth conifer forests to nest (up to $30 \mathrm{~km}$ from the shoreline)

55 and high-quality marine habitats to forage (mainly within $500 \mathrm{~m}$ of the shoreline; Hazlitt et

56 al. 2010). Ecosystem services are also being lost. It is estimated that coastal degradation leads

57 to $0.15-1.02$ billion $\mathrm{y}^{-1}$ tonnes of carbon dioxide being released from coastal ecosystems and 
58 direct economic damages arising from the loss of vegetated coastal ecosystems estimated at $59 \$ 6-42$ billion USD y ${ }^{-1}$ (Pendleton et al. 2012).

With as much as $74 \%$ of the world's population living within $50 \mathrm{~km}$ of the coast

61 (Small \& Nicholls 2003), understanding spatial patterns of human influence on coastal

62 regions is essential for identifying natural ecosystems that may be in crisis and require

63 conservation action, to ensure the long-term persistence of important ecological coastal

64 processes (Halpern et al. 2015). Human pressure maps have been developed for the terrestrial

and marine realms to inform conservation and management of biodiversity and ecosystem

services. At a global scale, the terrestrial human footprint (Venter et al. 2016b; Williams et al.

2020) and the marine cumulative human impact maps (Halpern et al. 2019) are a collation of

information from eight (e.g., built human environments, population density) and fourteen

large scale pressures (e.g., fishing activities, nutrient pollution), respectively. These maps

have been used to identify areas with low human pressure at different times, but these

analyses have been carried out separately for the land (Allan et al. 2017) and sea (Jones et al. 
83 region intactness at the global and national scales, ascertaining which nations contain Earth's

84 remaining intact coastal regions, and which have the greatest amounts that are degraded. We

85 then quantify human pressure across 11 coastal ecosystems to identify those most at risk, and

86 assess current levels of coastal protection. A Post-2020 Global Biodiversity Framework will

87 be soon agreed at the fifteenth conference of the parties to the Convention on Biological

88 Diversity with the goal of preventing the catastrophic loss of global biodiversity that delivers

89 multiple benefits to humanity (Díaz et al. 2019; Maxwell et al. 2020). Maintaining and

90 restoring coastal ecological integrity is key to meeting this goal, as well as other global

91 sustainability goals outlined by the United Nations' Sustainable Development Goals

92 (Neumann et al. 2017). Therefore, it is the right moment to evaluate the intensity of human

93 pressure along coastal regions, and to contextualise this assessment against the background of

94 global sustainability objectives to prioritise actions nations can undertake towards retaining,

95 sustainably managing, and restoring coastal regions to the benefit of both biodiversity and the

96 people who rely on them for survival. 


\section{Methods}

98

99

100

101

102

103

104

105

\section{Human pressure across coastal regions}

To represent human pressure on terrestrial Earth we used the recently released human footprint for the year 2013, which includes pressures on (1) the extent of built human environments, (2) population density, (3) electric infrastructure, (4) crop lands, (5) pasture lands, (6) roadways, (7) railways, and (8) navigable waterways (Venter et al. 2016a; Williams et al. 2020). For the marine environment, we used the cumulative human index, also for the year 2013 which includes pressures from four primary categories, (1) fishing: commercial demersal destructive, commercial demersal non-destructive high bycatch, commercial demersal non-destructive low bycatch, pelagic high bycatch, pelagic low bycatch, artisanal, (2) climate change: sea surface temperature, ocean acidification, sea-level rise (though this component was only used in the sensitivity analysis), (3) ocean: shipping, and (4) land-based: nutrient pollution, organic chemical pollution, direct human (population density), light (Halpern et al. 2019).

For the terrestrial human footprint $\left(1 \mathrm{~km}^{2}\right.$ resolution $)$, as per previous studies we defined intact land as anything below a threshold of <4 (Beyer et al. 2019; Williams et al. 2020). This threshold has been found to be robust from a species conservation perspective because, once surpassed, species extinction risk increases dramatically (Di Marco et al. 2018), and several ecosystem processes are altered (Crooks et al. 2017; Di Marco et al. 2018; Tucker et al. 2018). To identify intact areas within the marine realm we regard any value below the $40 \%$ quantile which equates to a threshold of $3.87 \mathrm{e}-2$ (of a total range of 0-12; Halpern et al. 2019), for the global cumulative human impact map (1 $\mathrm{km}^{2}$ resolution). Following Jones et al. 2018 (Jones et al. 2018) we excluded climate change variables (temperature and UV anomalies, ocean acidification, and sea-level rise) from the marine cumulative human pressure dataset, because the impacts of climate change are widespread 
122 and unmanageable at a local scale, and there are significant variations in exposure and

123 vulnerability across marine ecosystems (e.g., coral reefs versus deep sea). Additionally, the

124 terrestrial human footprint map does not include climate change stressors.

\section{Analysis}

126 We identify coastal regions as the transition between terrestrial and marine environments

127 based on the $1 \mathrm{~km}^{2}$ resolution pressure maps, and represented as points at approximately 1

$128 \mathrm{~km}$ distance intervals. We defined a $50 \mathrm{~km}$ radius buffer around each point which, following

129 Fang et al. 2018, captures important processes that occur in the coastal zone, including tidal,

130 breeding, and foraging migration of neritic animals, stranded dead marine products on the

131 shore, bird moving foraging, river nutrient transport, and saltwater intrusion (Appendix S1).

132 Spatial error in the location of the coastline points is small relative to the radius within which 133 pressures are quantified.

Intact coastal regions were identified by quantifying the proportion of intact land and sea areas within the $50 \mathrm{~km}$ radius of each coastal point (pixel in the human footprint dataset).

136 Any location containing less than 500 cells of either land or sea within the $50 \mathrm{~km}$ radius circle (and $30 \mathrm{~km}$ radius, 5 cells for the $10 \mathrm{~km}$ radius - see Sensitivity Analysis) was omitted from the analysis as the estimate of the proportion of intact area may be unreliable. This occasionally arises as a result of inconsistencies in the mapping of coastlines between the terrestrial and marine data sources. The average of the land and sea intact area proportions was used to characterise the intactness of land sea connected pixels. We divided this final combined metric into five equal bins $(0-0.2,0.2-0.4,0.4-0.6,0.6-0.8$ and $0.8-1)$ for reporting purposes. Using the global coastal intactness estimates, we summarise the distribution of coastal intactness by nation and for key coastal ecosystems, and assess their global protection status (Appendix S2). 


\section{$146 \quad$ Units of analysis}

147 We assessed the intactness of coastal regions in proximity to tidal flats (Murray et al. 2019),

148 saltmarshes (Mcowen et al. 2017), mangroves (Bunting et al. 2018), seagrasses (UNEP-

149 WCMC 2003), estuaries (Alder 2003), kelp forests (Mora-Soto et al. 2020), coral reefs

150 (UNEP-WCMC et al. 2018), savannah (Jung et al. 2020), deserts (Jung et al. 2020), rocky

151 areas (Jung et al. 2020) and forests (Jung et al. 2020). This was achieved by buffering the

152 polygons representing each habitat type by $50 \mathrm{~km}$ (a radius equal to the radius used to

153 quantify coastal intactness) and summarising the distribution of coastal intactness values

154 within the buffer. Hence, this is a measure of the intactness of the coastal regions influencing

155 these systems (Ray 1991; Fang et al. 2018), not of intactness within or around each of these

156 habitat types. To delineate national borders we used GADM national boundaries (Global

157 Administrative Areas 2012).

Data on protected area location, and boundary of protected areas were obtained from

the June 2019 version of the World Database on Protected Areas (WDPA; UNESCO 2020).

We incorporated into the June 2019 version of WDPA 768 protected areas $\left(1,425,770 \mathrm{~km}^{2}\right)$ in

China (sites that were available in the June 2017 version of WDPA, but not publicly available

162 thereafter). Following the WDPA best practice guidelines

163 (www.protectedplanet.net/c/calculating-protected-area-coverage) and other global studies

164 (Maxwell et al. 2020), we included in our analysis only protected areas from the WDPA database that have a status of 'Designated', 'Inscribed' or 'Established', and removed all points and polygons with a status of 'Proposed' or 'Not Reported'. We also removed all

167 points and polygons designated as 'UNESCO MAB Biosphere Reserves', as these do not 168 meet the IUCN definition of a protected area. We buffered the point feature class in 169 accordance to the point's area as stated in the 'REP_AREA' field, and merged the buffered 
170 points with polygons to create one polygon layer. To reduce computational burden, we

171 removed redundant vertices (tolerance was set at $1000 \mathrm{~m}$ ) in the polygon layer.

\section{Sensitivity analysis}

173 We carried out a sensitivity analysis in relation to our definition of the coastal region, with

174 buffer sizes of $30 \mathrm{~km}$ and $10 \mathrm{~km}$, rather than $50 \mathrm{~km}$. We found broadly similar patterns in the 175 distribution and relative frequency of intactness categories among these radii (Appendix S3 176 and Appendix S5).

For the terrestrial human footprint, an ecologically relevant threshold to define intact

habitat has been previously established (Di Marco et al. 2018). However, in the marine realm,

a threshold is yet to be ecologically defined and validated. We therefore also carried out our

analysis over a range of thresholds and definitions of intact in the marine environment. In the

main manuscript we present results where the threshold is set to below the $40 \%$ quantile. Our

sensitivity analysis included any value below the $20 \%$ quantile (excluding climate change

stressors), the average of all stressors for the year 2013 for below the $20 \%$ and $40 \%$ quantile,

the average of all stressors for the year 2013 for below the $20 \%$ and $40 \%$ quantile but

excluding climate change stressors, and the full cumulative human impact map for the year

1862013 (which includes climate change stressors) for below the $20^{\text {th }}$ and $40^{\text {th }}$ quantile. We

found similar trends between the five intactness categories across all definitions of intact in

the marine environment. Climate change stressors are the predominate driver of human

pressure in the marine environment, their inclusion quite obviously shifted the positioning of

the $40^{\text {th }}$ quantile compared to when they were excluded. This changed the results slightly, for 


\section{Results}

195

\section{The intactness of Earth's coastal regions}

Using this assessment approach we find that no coastal region is free from human influence (i.e., $100 \%$ intact) and only $15.5 \%$ of all coastal regions can be considered "low" in anthropogenic pressure ( $80-100 \%$ intact; Fig. 1$)$. Conversely $14.0 \%$ is exposed to extreme human pressure ( $0 \%$ intact), and $47.9 \%$ of coastal regions are exposed to high human pressure $0-20 \%$ intact. These coastal regions with high levels of human pressure are located across Earth, but are more concentrated in tropical and temperate regions (Fig. 1). There are more coastal regions that have low intactness in the marine realm but relatively high intactness in the terrestrial realm, than high intactness in both realms (Fig. 2).

Almost all of the most intact coastal regions are located in Canada, Russia, and Greenland (Fig. 1B). Canada is responsible for the largest expanse of coastal region that remains under very low anthropogenic pressure, with $53.4 \%$ of its coastal regions $(>60,855$ $\mathrm{km}$ or $7.93 \%$ of all coastal regions) falling within the highest intactness category $(>80 \%$ intact), followed by Russia 40.7\% (>34,737 $\mathrm{km}$ or $4.52 \%)$, and Greenland $44.1 \%(>19,176$ $\mathrm{km}$ or $2.50 \%$; Fig. 1B). Their relatively intact condition can likely be attributed to their remoteness from major urban and industrial centres, and inaccessibility during winter months (Halpern et al. 2008). We found 12 nations contain coastal regions that remain $>80 \%$ intact, and a further 9 contain coastal regions that remain relatively intact (60-80\% intact), with large expanses located in Chile, Australia, the United States, Svalbard, Indonesia, Papua New Guinea, the Falkland Islands, the Solomon Islands, and Brazil. At the other extreme, we found that all coastal regions of 26 nations are highly exposed to human pressures (i.e., $0 \%$ intact). Many of these were island nations including Singapore, Dominica, and Aruba, but also included mainland nations in Africa, and Asia (Fig. 1B; Appendix S7). 
219 We quantified human pressure across 11 coastal ecosystems (forests, rocky areas, savannah, 220 desert, coral reefs, estuaries, kelp forests, mangroves, salt marshes, seagrasses, tidal flats) and 221 found that more than $60.1 \%$ of the coastal regions containing these ecosystems is under high 222 levels of human pressure (0-20\% intact; Fig. 3). Human pressure is highest across the coastal

223 regions with seagrasses, savannah, and coral reefs; $80.0 \%$ of coastal regions adjacent to 224 seagrass $(>195,775 \mathrm{~km}), 77.3 \%$ adjacent to savannah $(>138,594 \mathrm{~km})$, and $73.8 \%$ adjacent to 225 coral reefs $(>172,502 \mathrm{~km})$ are exposed to high human pressures (0-20\% intact; Fig. 3).

226 Deserts, forests, and salt marshes are the coastal habitats that have the most area within intact 227 regions (80-100\% intact), but this is only $3.90 \%, 1.21 \%$, and $0.48 \%$ of Earth's coastal 228 regions, respectively (Fig. 3; Appendix S6).

\section{Current levels of coastal protection}

230 Of the $16.4 \%$ of coastal regions falling within designated, inscribed, or established (World 231 Database on Protected Areas; UNESCO 2020) protected areas (either in the terrestrial or 232 marine environment), $43.3 \%$ are exposed to high human pressures (0-20\% intact). The United 233 States, Russia, Canada, and Greenland, have the most coastal region protected (in terms of 234 area), whereas Greenland, Canada, and Svalbard have the most coastal regions of high 235 intactness protected (Fig. 4). We found $61.9 \%$ of protected coastal regions $(>257,004 \mathrm{~km})$

236 was protected in both the terrestrial and marine environments, the remaining $38.1 \%$ was 237 protected only in one realm (11.2\% marine, $88.8 \%$ terrestrial). 


\section{Discussion}

239 It is safe to say intact coastal regions are now rare. This has profound implications for coastal

240 biodiversity (Hazlitt et al. 2010; Rogers \& Mumby 2019), and for humanity, as we rely on

241 functioning coastal ecosystems for ecosystem services such as climate change mitigation,

242 food provision, and storm protection (Mcleod et al. 2011; Pendleton et al. 2012; Ferrol-

243 Schulte et al. 2013). Many of the coastal regions that remain intact are at higher latitudes, so

244 broad-scale restoration is required across much of Earth's coastal regions. However, where

245 and how to restore, protect, or manage varies depending on the levels of human pressure

246 coastal regions are experiencing (Darling et al. 2019).

Relatively intact coastal regions will require different conservation implementation strategies to conserving the last remaining intact pockets (areas of low human pressure surrounded by areas of higher human pressure), which can provide benefits to surrounding locations of lower integrity (Cinner et al. 2020). For example, in northwest Greenland conserving long stretches of sea ice, arctic water, and glacier habitats will require enhancing environmental governance and laws around encroaching development and addressing climate change (climate change stressors are not included in the results of the main manuscript; however, we include them for the marine realm in the sensitivity analysis (see Appendix S4 and Appendix S5)) (Nuttall 2020). Here, and across many other coastal regions, strengthening Indigenous peoples' involvement in managing coastal environments will be

257 vital to long-term coastal sustainability. In contrast, conserving the remaining intact pockets of coastlines, like those on the coastal region encompassing Collingwood Bay in Papua New

259 Guinea, which is relied on by local communities for ecosystem services (Poloczanska et al.

260 2011), and areas in the Tambelan Archipelago in Indonesia, where the coastal ecosystems are 261 known nurseries for fish species (Yonvitner \& Fahmi 2012), will rely on specific management actions by local communities. In Collingwood Bay land owners have been 
263 battling illegal logging for decades - here conservation success will take the form of complex 264 socio-political action to address largely land-based stressors (McDonnell et al. 2017). Efforts 265 such as the analysis presented here can help differentiate this spectrum of human pressure at a 266 broad scale, to drive localized assessments to inform actions on the ground (Cross et al. 267 2012).

Encouragingly we found that $61.9 \%$ of protected coastal regions are protected in both the terrestrial and marine realms, rather than protection occurring in just one realm. Examples include the Patagonia Fjords of southern Chile, some locations along the Australian coast

271 (including many wetland ecosystems) adjacent to the Great Barrier Reef, and the Iguape-

272 Cananéia-Paranaguá estuary in the state of Paraná in Brazil. Management strategies here consider the coastal interface through community and local engagement to better understand degrading processes (Anbleyth-Evans et al. 2020), retention of riparian coastal ecosystems to prevent nutrient and sediment run-off from surrounding agricultural lands (Kroon et al. 2016), and effectively managing fishing resources (Mendonça et al. 2010). These examples should be showcased and implemented more broadly.

279 Earth's coastal regions. As the $16.4 \%$ of coastal regions under formal protection are under high levels of human pressure, increasing well-resourced protected areas is an important priority (Fraschetti et al. 2009), but they must be accompanied by other effective area-based conservation measures (OECMs) (Cinner et al. 2020), and non-area based management (Wenger et al. 2018a) to deliver biodiversity and ecosystem service benefits. OECMs are likely going to be an increasingly important coastal management strategy, as they can be an opportunity to conserve nature while ensuring community rights are recognised and that communities are enfranchised to manage their own resources while delivering biodiversity and ecosystem service benefits (Dudley et al. 2018). This is particularly acute in the intact 
288 coastal areas of the arctic, which are the homelands for diverse groups of indigenous peoples, 289 each with their own distinct cultures, histories and livelihood practices such as reindeer 290 herding, subsistence whale and seal hunting, and commercial fisheries. In these cases, it will 291 be crucial to work with these communities to maintain the ecological integrity of these intact 292 coasts in the face of industrial development pressures, while harnessing their traditional 293 ecological knowledge for the process of adapting to climate change (Fondahl et al. 2015; 294 Gassiy \& Potravny 2019). Non-area based management approaches such as mitigating land295 use change to prevent increased pollution run-off (Hamilton et al. 2017), or enhanced 296 regulation of degrading activities (Wenger et al. 2018b) will also play a crucial role. These 297 conservation actions must be implemented with careful consideration of the often over looked 298 land-sea connection that coastal regions encompass, rather than independent land or sea 299 initiatives (Jupiter et al. 2017).

Given the widespread human pressure we have revealed across coastal regions (Fig. 1, Fig. 3), there is a fundamental role for active restoration in many nations (Saunders et al. 2017). Priorities for coastal restoration should be informed by levels of human pressure, as it will depend on the removal of threats (Borja et al. 2010) and targeted management of anthropogenic activities such as nutrient run-off (Duarte et al. 2020). Sea-level rise as a consequence of climate change is also leading to coastal flood and erosion risks, inciting efforts to restore defence ecosystems either to their natural state or replicate their function through artificial structures (Pontee et al. 2016). But these restoration actions must also be informed by regional assessments of ecological integrity and feasibility of success (Bayraktarov et al. 2016). Some locations may be so degraded that the cost-benefit ratio of active restoration may be high, and other types of conservation actions such as passive 311 restoration, off-setting or relocation of species may be warranted (Gayle et al. 2005). 
312 Our analysis is the first to integrate the terrestrial and marine human pressure maps

313 for coastal regions. As both maps were created independently, there are inherent limitations

314 in their congruence. As identifying intact areas requires finding those areas that have little to

315 no impact across all human activities (Jones et al. 2018), for the marine realm we regard

316 intact as any value below the $40 \%$ quantile in the cumulative human impact map. Future

317 studies may follow assessments that have been carried out on land and empirically assess the

318 ecological significance of this threshold (Di Marco et al. 2018). In addition, climate change

319 stressors, including ocean acidification, sea surface temperature, and sea-level rise, were

320 omitted from the marine cumulative human impact dataset for the purpose of this analysis

321 (but see the sensitivity analysis, Appendix S4 and Appendix S5 for results when they are

322 included). However, climate change threatens most coastal regions through changes to

323 biophysical and socioeconomic processes that can be difficult to predict. This analysis

324 therefore represents an optimistic assessment of ecosystem intactness in the context of future

325 climate change impacts that are likely to arise with increasing frequency over the coming

326 decades (IPPC 2018).

Our research shows that humanity's impact on Earth's coastal regions is severe and

widespread. In order to meet global conservation and sustainability goals, it is crucial that

nations implement conservation activities to retain their remaining intact coastal regions.

330 Nations like Russia, Canada and Greenland can play a significant role by proactively

protecting the last great intact coastal regions on Earth. Most coastal nations have small

pockets of intact coastal regions and it is particularly important to maintain these

environments. Our research also shows that it is now critical the global community set

335 Decade for Ecosystem Restoration efforts that are underway. 


\section{Supporting Information}

337 Definition of coastal region (Appendix S1), a flow diagram of the methods used to calculate

338 coastal region intactness (Appendix S2), coastal region intactness using a buffer size of a) 10

$339 \mathrm{~km}$ and b) $30 \mathrm{~km}$ as opposed to $50 \mathrm{~km}$ as a sensitivity analysis (Appendix S3), coastal region

340 intactness using a range of thresholds and definitions of intact in the marine environment as a

341 sensitivity analysis (Appendix S4), coastal region intactness (number of points) using a range

342 of buffers sizes to define coastal region, and definitions of intact in the marine environment

343 from the sensitivity analysis to determine percentage intact (Appendix S5), distribution of

344 intactness values (number of points) of coastal regions in proximity $(<50 \mathrm{~km})$ to 11 coastal

345 ecosystem types (Appendix S6), and the amount (number of points) of each country's coastal

346 regions and their percentage intactness (0-100\%) (Appendix S7). The authors are solely

347 responsible for the content and functionality of these materials. Queries (other than absence

348 of the material) should be directed to the corresponding author.

\section{Acknowledgements}

351 BAW and LAR were supported by an Australian Government Research Training Program

352 Scholarship. CJK was funded by a University of Queensland Fellowship and the Australian

353 Research Council. The authors declare no competing interests. 


\section{References}

Alder J. 2003. Putting the coast in the Sea Around Us project. The Sea Around Us Newsletter 15:1-2.

Allan JR, Venter O, Watson JEM. 2017. Temporally inter-comparable maps of terrestrial wilderness and the Last of the Wild. Scientific data 4:170187. Nature Publishing Group.

Anbleyth-Evans J, Leiva FA, Rios FT, Cortés RS, Häussermann V, Aguirre-Munoz C. 2020. Toward marine democracy in Chile: Examining aquaculture ecological impacts through common property local ecological knowledge. Marine Policy 113:103690. Elsevier.

Barbier EB. 2015. Valuing the storm protection service of estuarine and coastal ecosystems. Ecosystem Services 11:32-38. Elsevier.

Barbier EB, Hacker SD, Kennedy C, Koch EW, Stier AC, Silliman BR. 2011. The value of estuarine and coastal ecosystem services. Ecological monographs 81:169-193. Wiley Online Library.

Bayraktarov E, Saunders MI, Abdullah S, Mills M, Beher J, Possingham HP, Mumby PJ, Lovelock CE. 2016. The cost and feasibility of marine coastal restoration. Ecological Applications 26:1055-1074. Wiley Online Library.

Beyer HL, Venter O, Grantham HS, Watson JEM. 2019. Substantial losses in ecoregion intactness highlight urgency of globally coordinated action. Conservation Letters 13:e12592. Society for Conservation Biology.

Borja Á, Dauer DM, Elliott M, Simenstad CA. 2010. Medium-and long-term recovery of estuarine and coastal ecosystems: patterns, rates and restoration effectiveness. Estuaries and Coasts 33:1249-1260. Springer.

Bunting P, Rosenqvist A, Lucas RM, Rebelo L-M, Hilarides L, Thomas N, Hardy A, Itoh T, Shimada M, Finlayson CM. 2018. The global mangrove watch-a new 2010 global baseline of mangrove extent. Remote Sensing 10:1669. Multidisciplinary Digital Publishing Institute.

Cinner J. 2014. Coral reef livelihoods. Current Opinion in Environmental Sustainability 7:65-71. Elsevier.

Cinner JE, Zamborain-Mason J, Gurney GG, Graham NAJ, MacNeil MA, Hoey AS, Mora C, Villéger S, Maire E, McClanahan TR. 2020. Meeting fisheries, ecosystem function, and biodiversity goals in a human-dominated world. Science 368:307-311. American Association for the Advancement of Science.

Crooks KR, Burdett CL, Theobald DM, King SRB, Di Marco M, Rondinini C, Boitani L. 2017. Quantification of habitat fragmentation reveals extinction risk in terrestrial mammals. Proceedings of the National Academy of Sciences 114:7635-7640. National Acad Sciences.

Cross MS, Zavaleta ES, Bachelet D, Brooks ML, Enquist CAF, Fleishman E, Graumlich LJ, Groves CR, Hannah L, Hansen L. 2012. The Adaptation for Conservation Targets (ACT) framework: a tool for incorporating climate change into natural resource management. Environmental Management 50:341-351. Springer.

Darling ES, McClanahan TR, Maina J, Gurney GG, Graham NAJ, Januchowski-Hartley F, Cinner JE, Mora C, Hicks CC, Maire E. 2019. Social-environmental drivers inform 
strategic management of coral reefs in the Anthropocene. Nature ecology \& evolution 3:1341-1350. Nature Publishing Group.

Di Marco M, Venter O, Possingham HP, Watson JEM. 2018. Changes in human footprint drive changes in species extinction risk. Nature communications 9:4621. Nature Publishing Group.

Díaz S, Settele J, Brondízio E, Ngo H, Guèze M, Agard J, Arneth A, Balvanera P, Brauman K, Butchart S. 2019. Summary for policymakers of the global assessment report on biodiversity and ecosystem services of the Intergovernmental Science-Policy Platform on Biodiversity and Ecosystem Services. IPBES secretariat, Bonn, Germany.

Duarte CM, Agusti S, Barbier E, Britten GL, Castilla JC, Gattuso J-P, Fulweiler RW, Hughes TP, Knowlton N, Lovelock CE. 2020. Rebuilding marine life. Nature 580:39-51. Nature Publishing Group.

Dudley N, Jonas H, Nelson F, Parrish J, Pyhälä A, Stolton S, Watson JEM. 2018. The essential role of other effective area-based conservation measures in achieving big bold conservation targets. Global ecology and conservation 15:e00424. Elsevier.

Fang X, Hou X, Li X, Hou W, Nakaoka M, Yu X. 2018. Ecological connectivity between land and sea: a review. Ecological research 33:51-61. Wiley Online Library.

Ferrol-Schulte D, Wolff M, Ferse S, Glaser M. 2013. Sustainable Livelihoods Approach in tropical coastal and marine social-ecological systems: A review. Marine policy 42:253258. Elsevier.

Fondahl G, Filippova V, Mack L. 2015. Indigenous peoples in the new Arctic. Pages 7-22 The New Arctic. Springer.

Fraschetti S, D’Ambrosio P, Micheli F, Pizzolante F, Bussotti S, Terlizzi A. 2009. Design of marine protected areas in a human-dominated seascape. Marine Ecology Progress Series 375:13-24.

Gassiy V, Potravny I. 2019. The compensation for losses to indigenous peoples due to the Arctic industrial development in benefit sharing paradigm. Resources 8:71. Multidisciplinary Digital Publishing Institute.

Gayle PMH, Wilson-Kelly P, Green S. 2005. Transplantation of benthic species to mitigate impacts of coastal development in Jamaica. Revista de Biología Tropical 53:105-115. http://creativecommons. org/licenses/by/3.0.

Global Administrative Areas. 2012. GADM database of global administrative areas. Global Administrative Areas.

Halpern BS, Frazier M, Afflerbach J, Lowndes JS, Micheli F, O’Hara C, Scarborough C, Selkoe KA. 2019. Recent pace of change in human impact on the world's ocean. Scientific reports 9:11609. Nature Publishing Group.

Halpern BS, Frazier M, Potapenko J, Casey KS, Koenig K, Longo C, Lowndes JS, Rockwood RC, Selig ER, Selkoe KA. 2015. Spatial and temporal changes in cumulative human impacts on the world's ocean. Nature communications 6:7615. Nature Publishing Group.

Halpern BS, Walbridge S, Selkoe KA, Kappel C V, Micheli F, D’agrosa C, Bruno JF, Casey KS, Ebert C, Fox HE. 2008. A global map of human impact on marine ecosystems. 
Science 319:948-952. American Association for the Advancement of Science.

439

440

441

442

443

444

445

446

447

448

449
Hamilton RJ, Almany GR, Brown CJ, Pita J, Peterson NA, Choat JH. 2017. Logging degrades nursery habitat for an iconic coral reef fish. Biological Conservation 210:273280. Elsevier.

Hazlitt SL, Martin TG, Sampson L, Arcese P. 2010. The effects of including marine ecological values in terrestrial reserve planning for a forest-nesting seabird. Biological Conservation 143:1299-1303. Elsevier.

IPPC. 2018. Special Report: Global Warming of $1.5^{\circ} \mathrm{C}$ - Summary for Policymakers. Available from https://www.ipcc.ch/sr15/chapter/summary-for-policy-makers/.

Jones KR, Klein CJ, Halpern BS, Venter O, Grantham H, Kuempel CD, Shumway N, Friedlander AM, Possingham HP, Watson JEM. 2018. The location and protection status of Earth's diminishing marine wilderness. Current Biology 28:2506-2512. Elsevier.

Jung M, Dahal PR, Butchart SHM, Donald PF, De Lamo X, Lesiv M, Kapos V, Rondinini C, Visconti P. 2020. A global map of terrestrial habitat types. Scientific data 7:1-8. Nature Publishing Group.

Jupiter SD, Wenger A, Klein CJ, Albert S, Mangubhai S, Nelson J, Teneva L, Tulloch VJ, White AT, Watson JEM. 2017. Opportunities and constraints for implementing integrated land-sea management on islands. Environmental Conservation 44:254-266. Cambridge University Press.

Kroon FJ, Thorburn P, Schaffelke B, Whitten S. 2016. Towards protecting the Great Barrier Reef from land $\square$ based pollution. Global change biology 22:1985-2002. Wiley Online Library.

Maxwell SL, Cazalis V, Dudley N, Hoffmann M, Rodrigues ASL, Stolton S, Visconti P, Woodley S, Maron M, Strassburg BBN. 2020. Area-Based Conservation in the 21st Century. Nature 586:217-227. Nature Publishing Group.

McDonnell S, Allen M, Filer C. 2017. Kastom, property and ideology: Land transformations in Melanesia. Page (McDonnell S, Allen MG, Filer C, editors)State, soc. ANU Press.

Mcleod E, Chmura GL, Bouillon S, Salm R, Björk M, Duarte CM, Lovelock CE, Schlesinger WH, Silliman BR. 2011. A blueprint for blue carbon: toward an improved understanding of the role of vegetated coastal habitats in sequestering CO2. Frontiers in Ecology and the Environment 9:552-560. Wiley Online Library.

Mcowen CJ, Weatherdon L V, Van Bochove J-W, Sullivan E, Blyth S, Zockler C, StanwellSmith D, Kingston N, Martin CS, Spalding M. 2017. A global map of saltmarshes. Biodiversity data journal 5:e11764. Pensoft Publishers.

Mendonça JT, Verani JR, Nordi N. 2010. Evaluation and management of blue crab Callinectes sapidus (Rathbun, 1896)(Decapoda-Portunidae) fishery in the Estuary of Cananéia, Iguape and Ilha Comprida, São Paulo, Brazil. Brazilian Journal of Biology 70:37-45. SciELO Brasil.

Mora-Soto A, Palacios M, Macaya EC, Gómez I, Huovinen P, Pérez-Matus A, Young M, Golding N, Toro M, Yaqub M. 2020. A High-Resolution Global Map of Giant Kelp (Macrocystis pyrifera) Forests and Intertidal Green Algae (Ulvophyceae) with Sentinel2 Imagery. Remote Sensing 12:694. Multidisciplinary Digital Publishing Institute. 
Murray NJ, Phinn SR, DeWitt M, Ferrari R, Johnston R, Lyons MB, Clinton N, Thau D, Fuller RA. 2019. The global distribution and trajectory of tidal flats. Nature 565:222225. Nature Publishing Group.

Neumann B, Ott K, Kenchington R. 2017. Strong sustainability in coastal areas: a conceptual interpretation of SDG 14. Sustainability science 12:1019-1035. Springer.

Nuttall M. 2020. Water, ice, and climate change in northwest Greenland. Wiley Interdisciplinary Reviews: Water 7:e1433. Wiley Online Library.

Pendleton L, Donato DC, Murray BC, Crooks S, Jenkins WA, Sifleet S, Craft C, Fourqurean JW, Kauffman JB, Marbà N. 2012. Estimating global "blue carbon" emissions from conversion and degradation of vegetated coastal ecosystems. PloS one 7:e43542. Public Library of Science.

Poloczanska KW, Brewer D, McLeod I, Rochester W, Sun C, Long B, Mitchell D. 2011. Melanesian coastal and marine ecosystem assets: assessment framework and Milne Bay case study. CSIRO Final Report to the CSIRO AusAID Alliance.

Pontee N, Narayan S, Beck MW, Hosking AH. 2016. Nature-based solutions: lessons from around the world. Pages 29-36 Proceedings of the Institution of Civil EngineersMaritime Engineering. Thomas Telford Ltd.

Ray GC. 1991. Coastal-zone biodiversity patterns. Bioscience 41:490-498. JSTOR.

Rogers A, Mumby PJ. 2019. Mangroves reduce the vulnerability of coral reef fisheries to habitat degradation. PLoS biology 17:e3000510. Public Library of Science San Francisco, CA USA.

Saunders MI, Bode M, Atkinson S, Klein CJ, Metaxas A, Beher J, Beger M, Mills M, Giakoumi S, Tulloch V. 2017. Simple rules can guide whether land-or ocean-based conservation will best benefit marine ecosystems. PLoS biology 15:e2001886. Public Library of Science.

Small C, Nicholls RJ. 2003. A global analysis of human settlement in coastal zones. Journal of coastal research 19:584-599. JSTOR.

Tucker MA, Böhning-Gaese K, Fagan WF, Fryxell JM, Van Moorter B, Alberts SC, Ali AH, Allen AM, Attias N, Avgar T. 2018. Moving in the Anthropocene: Global reductions in terrestrial mammalian movements. Science 359:466-469. American Association for the Advancement of Science.

UNEP-WCMC. 2003. Global distribution of seagrasses (version 6.0). Sixth update to the data layer used in Green and Short (2003). Cambridge (UK): UN Environment World Conservation Monitoring Centre.

UNEP-WCMC, WorldFish Centre, WRI, TNC. 2018. Global distribution of warm-water coral reefs, compiled from multiple sources including the Millennium Coral Reef Mapping Project. UNEP World Conservation Monitoring Centre Cambridge, UK. Available from https://doi.org/10.34892/t2wk-5t34.

UNESCO. 2020. World Database on Protected Areas WDPA. Available from https://www.protectedplanet.net/.

Venter O et al. 2016a. Global terrestrial Human Footprint maps for 1993 and 2009. Scientific data 3:1-10. Nature Publishing Group. 
522 Venter O, Sanderson EW, Magrach A, Allan JR, Beher J, Jones KR, Possingham HP, Laurance WF, Wood P, Fekete BM. 2016b. Sixteen years of change in the global terrestrial human footprint and implications for biodiversity conservation. Nature communications 7:1-11. Nature Publishing Group.

Vo QT, Kuenzer C, Vo QM, Moder F, Oppelt N. 2012. Review of valuation methods for mangrove ecosystem services. Ecological indicators 23:431-446. Elsevier.

Watson JEM, Venter O. 2019. Mapping the continuum of humanity's footprint on land. OneEarth 1:175-180. Cell Press.

Wenger AS, Atkinson S, Santini T, Falinski K, Hutley N, Albert S, Horning N, Watson JEM, Mumby PJ, Jupiter SD. 2018a. Predicting the impact of logging activities on soil erosion and water quality in steep, forested tropical islands. Environmental Research Letters 13:44035. IOP Publishing.

Wenger AS, Rawson CA, Wilson S, Newman SJ, Travers MJ, Atkinson S, Browne N, Clarke D, Depczynski M, Erftemeijer PLA. 2018b. Management strategies to minimize the dredging impacts of coastal development on fish and fisheries. Conservation Letters 11:e12572. Wiley Online Library.

Williams BA et al. 2020. Change in terrestrial human footprint drives continued loss of intact ecosystems. OneEarth 3:371-382. Cell Press.

Yonvitner, Fahmi. 2012. Population dynamics of dominant demersal fishes caught in Tambelan Islands waters, Riau Archipelago Province. Biodiversitas Journal of Biological Diversity 13:200-204. 
bioRxiv preprint doi: https://doi.org/10.1101/2021.05.10.443490; this version posted May 12, 2021. The copyright holder for this preprint (which was not certified by peer review) is the author/funder. All rights reserved. No reuse allowed without permission.

\section{$545 \quad$ Figures}

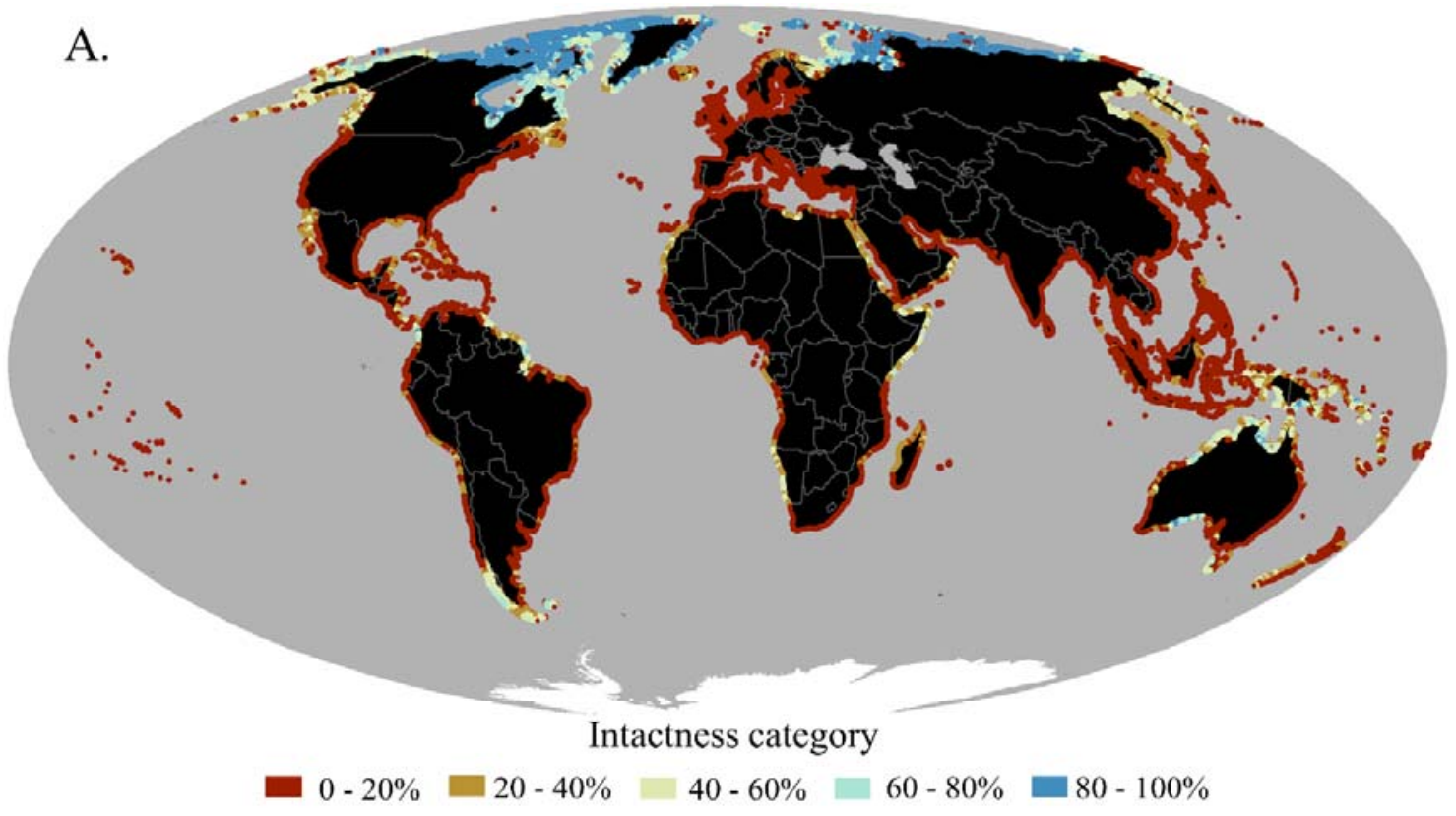

B.

Proportion of coastal areas in each category

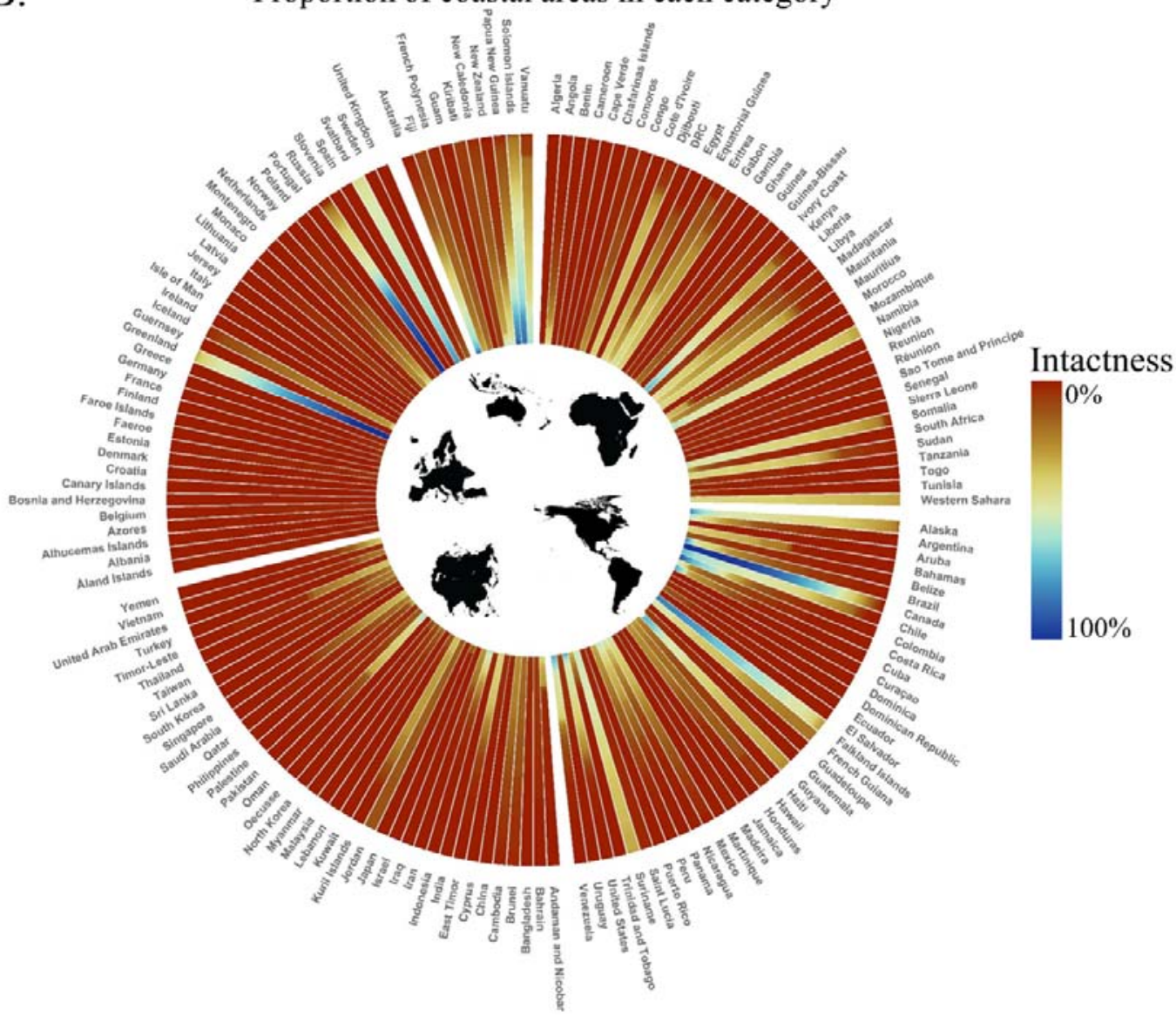


548 Figure 1. Intactness of Earth's coastal regions (A) and the proportion of each country's

549 coastal regions that are intact (across a scale of 0-100\%; B). For the terrestrial realm we

550 define intactness using the terrestrial human footprint (under a threshold of $<4$, representing a

551 reasonable approximation of when anthropogenic land conversion has occurred to an extent

552 that the land can be considered human-dominated; Williams et al. 2020), and for the marine

553 realm we use the cumulative human impact dataset (under a threshold of the $40 \%$ quantile -

554 and excluding climate change pressures; Halpern et al. 2019). 


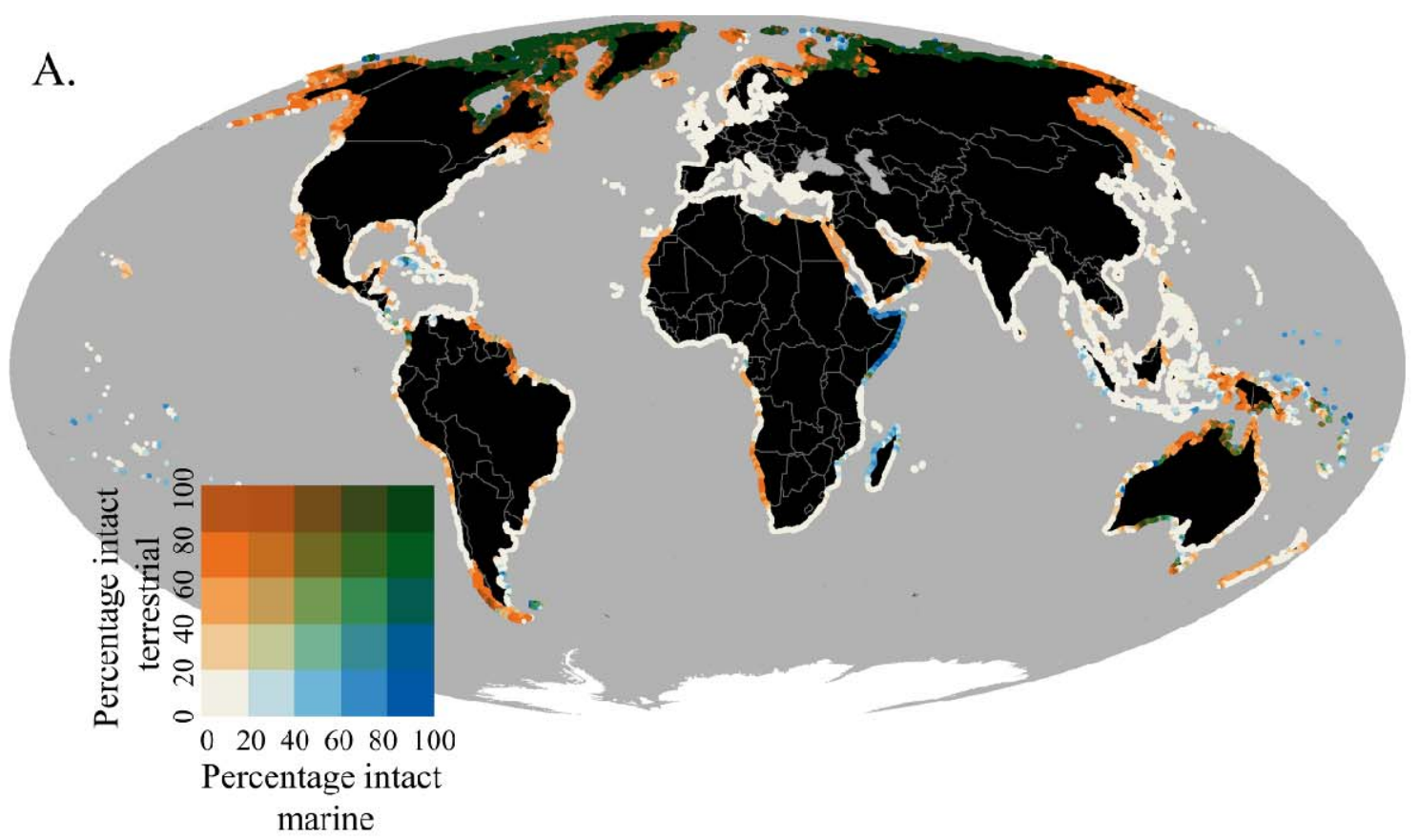

B.

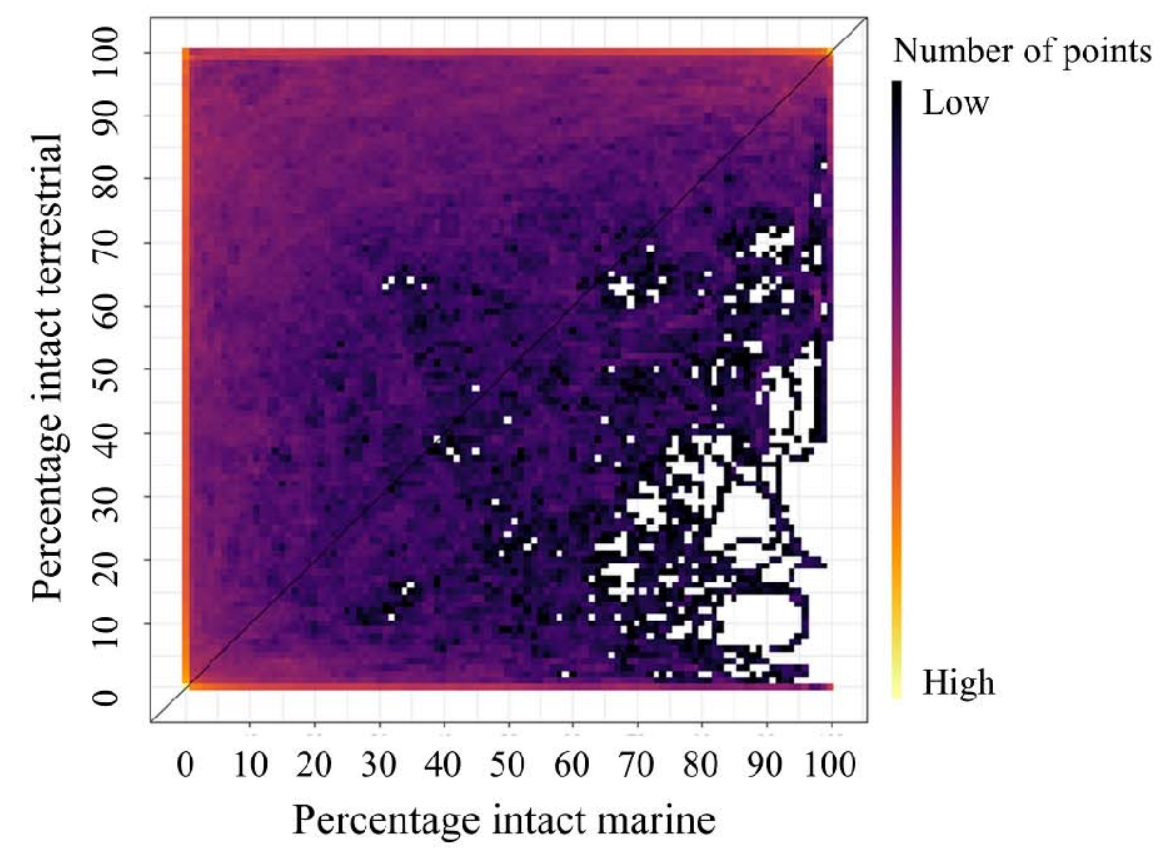

559 Figure 2. (A) The spatial relationship between intactness in the terrestrial and the marine

560 realms. (B) A heat map of the number of points (ranging from 1 to 249,136) and the

561 corresponding proportion within the $50 \mathrm{~km}$ buffer that is intact in the marine realm (x-axis; 
562 under a threshold of the $40 \%$ quantile (Halpern et al. 2019)) and in the terrestrial realm (y-

563 axis; under a threshold of $<4$ (Williams et al. 2020)).

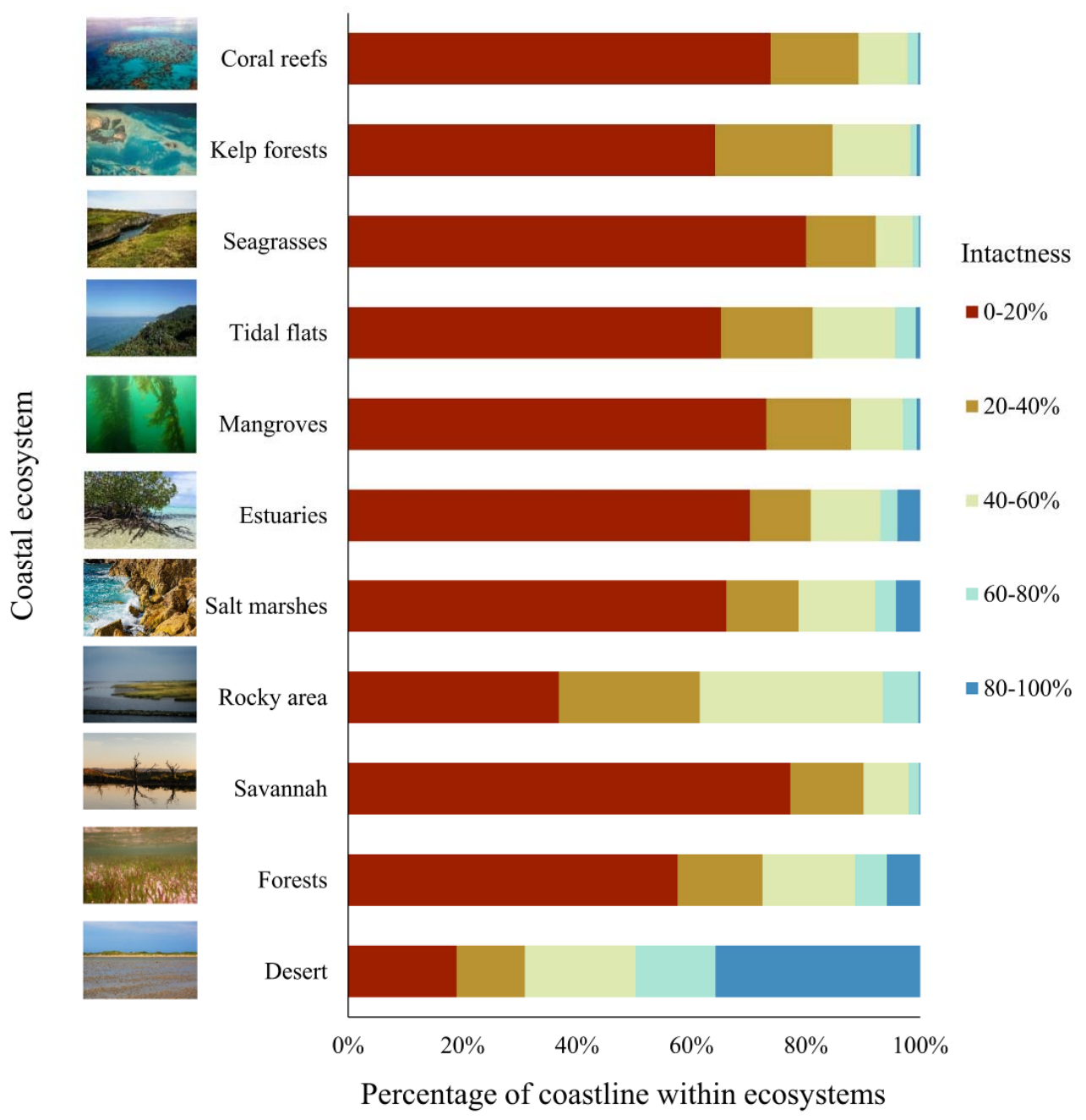

565 Figure 3. Distribution of intactness values of coastal regions in proximity $(<50 \mathrm{~km})$ to eleven

566 coastal ecosystem types. Photo credits - Coastal forest @ B Brooke Williams, Kelp forest and

567 Seagrasses (C) Megan Saunders, Mangroves ( Leslie Roberson, all other images are @

568 creative commons. 


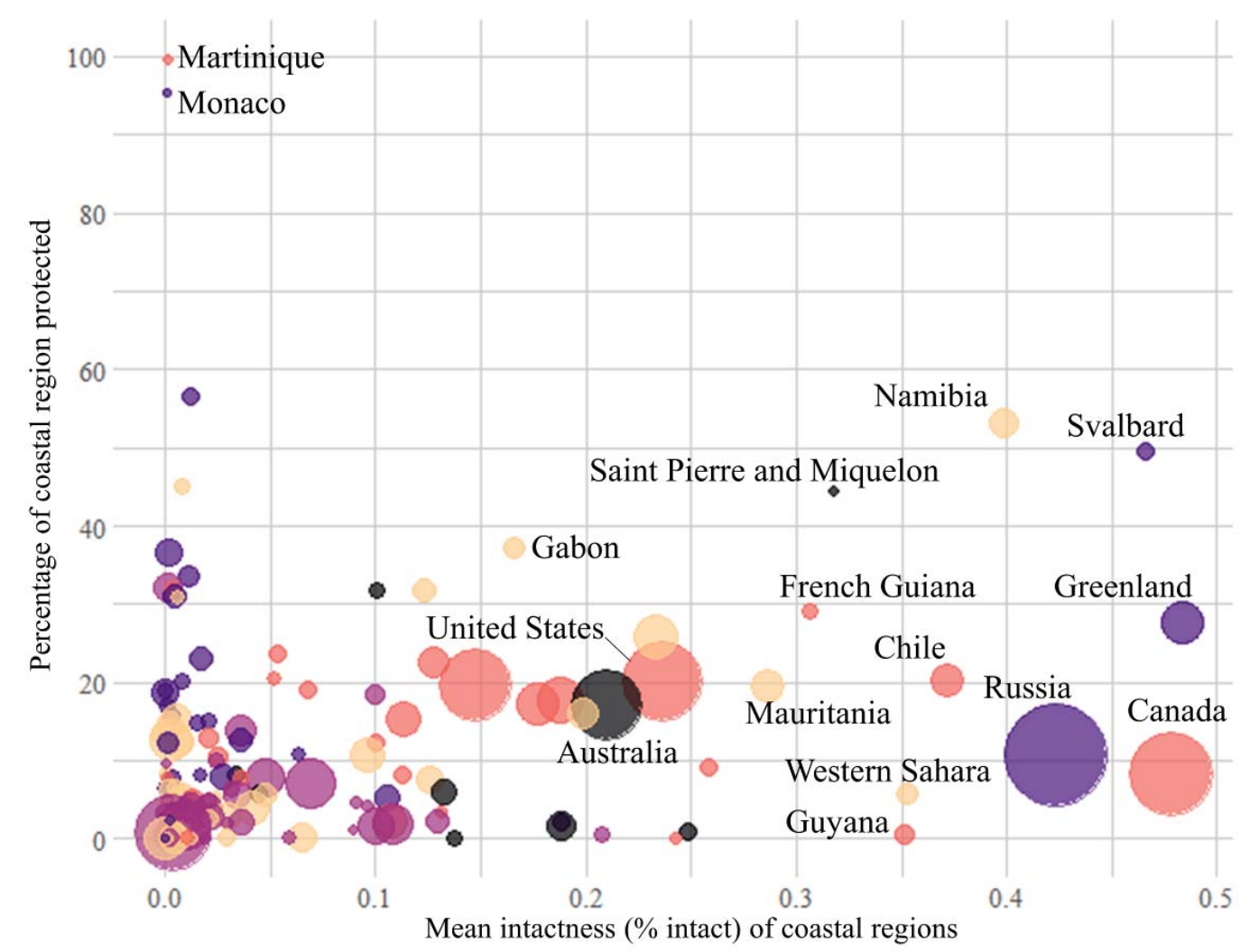

Figure 4. The percentage of each countries coastal region that is protected (World Database

571 on Protected Areas (WDPA; UNESCO 2020) that have a status of 'Designated', 'Inscribed'

572 or 'Established') plotted against the mean intactness of coastal regions. Bubble sizes

573 represent relative country size and suites of colours represent bio-geographic regions (Asia -

574 light purple, Oceania - black, Europe - dark purple, America - pink, or Africa - cream). 